\title{
O HORIZONTE DA ETICIDADE EM NIETZSCHE
}

\author{
Vânia Dutra de Azeredo \\ (Pontifícia Universidade de Campinas)
}

\begin{abstract}
Mesmo hoje, um século depois da interrupção das investigações filosóficas de Nietzsche, sua obra permite a introdução de um leitmotiv pouco investigado ou mesmo não tematizado pela maior parte dos intérpretes. É o caso da afirmação da presença de uma ética, mesmo que encoberta pelo peso da crítica acirrada à moral. Se há um certo consenso quanto ao reconhecimento de que a vertente iconoclasta do filósofo perpassa sua abordagem acerca do agir, existem poucas considerações referentes a uma possível positividade no sentido da tentativa de elaboração de uma nova perspectiva ética. Ainda assim, em nossa ótica, consideramos ser esse o motivo condutor tanto de sua crítica veemente à moralidade quanto da introdução de novos conceitos, especialmente, o de além-homem.

Em Peter Berkowitz ${ }^{1}$, encontramos uma leitura que considera a proposição de uma ética como questão central no pensamento de Nietzsche. Denominada de uma ética da criatividade, sua exposição apresenta uma forma de vida à qual devem ajustar-se os que querem ser criadores em vivendo, ao mesmo tempo, uma ética de criatividade e de autodeificação. Mas é de outra forma que interpretamos uma ética na filosofia do autor de Ecce homo, pois consideramos que a revisão do significado conferido ao trágico conduz Nietzsche ao ético. Reconhecemos que o filósofo substitui o elo entre dionisíaco e eticidade pelo enunciado previamente em relação à arte. Se a compreensão estética do mundo possibilitava desvencilhar-se da moral em $O$ nascimento da tragédia, será sua compreensão ética que permitirá dissolver a moral da responsabilidade, da auto-renúncia e do sacrifício de si em prol da aceitação/afirmação da vida enquanto atitude ética a partir de Assim falava Zaratustra. Ao partirmos do trágico, apro-
\end{abstract}

1 Peter BERKOWITZ, Nietzsche the Ethics of an Inmoralist, Massachusetts, Harvard University Press, 1996, p. 208.

Philosophica, 32, Lisboa, 2008, pp. 149-166 
ximamo-nos da perspectiva de $\mathrm{Haar}^{2}$ enquanto reconhece a presença de uma ética no pensamento de Nietzsche desde a afirmação dionisíaca do mundo. Mas dele nos distanciamos quando identifica nela algo de sagrado, o ideal de uma humanidade futura bem como a tudo que porta o porvir, expressando, assim, uma religião do $\mathrm{sim}^{3}$. Consideramos a dimensão do trágico como caminho que conduz ao ético enquanto revê o sentido do dionisíaco e, com isso, suporta a construção de uma visão ética do mundo.

Comecemos por caracterizar o trágico em Nietzsche mediante a proposição do caráter irrestrito de afirmação da vida: "[o] dizer Sim à vida mesma ainda em seus problemas mais estranhos e mais duros" (EH. $O$ nascimento da tragédia, § 3). Nele o pensador incorpora a problematicidade do existir em uma dimensão de necessidade positiva. É próprio do vir-a-ser o criar e o destruir; logo, o adentra-lo e o compreende-lo pressupõem de início a sua afirmação. A relação estabelecida entre o prazer, ao mesmo tempo, no vir-a-ser e no destruir remete à assimilação afirmativa do caráter problemático da existência. Ao apreendê-la a partir da perspectiva de uma eternidade de criação e de destruição constantes, ao afirmar, ao mesmo tempo, as belezas e os horrores da vida e da condição humana, Nietzsche estaria, pela primeira vez, promovendo a abertura para o vir-a-ser e, com isso, realizando a "transposição do dionisíaco em pathos filo-

\footnotetext{
2 Michel Haar, Par-delà le nihilisme, Paris, PUF, 1998, p. 2.

3 Existem outras formas de reconhecimento da presença, não propriamente de uma ética, mas de uma regra prática ou de um tipo de imperativo no pensamento do autor de Assim falava Zaratustra, mas são pautadas exclusivamente pela doutrina do eterno retorno. A formulação apresentada por Nietzsche em A gaia ciência: " Você quer isso mais uma vez e por incontáveis vezes?" (GC § 341) serviria de base, por exemplo, para a introdução de uma lei prática no seu pensamento na visão de Gilles Deleuze (Nietzsche et la philosophie, Paris, PUF, 1970, 77-82) e de um imperativo existencial na ótica de Magnus (Cf. Brend Magnus, Nietzsche existencial imperative, Blomington \& London, Indiana University Press, 1978, pp. 112-153). Ao entendermos o eterno retorno como círculo mundano de interpretações, vemos sua inclusão na filosofia de Nietzsche ser determinada pela suspensão da progressão da idéia na História da Filosofia. De fato, o filósofo procura suprimir a distinção mundo verdadeiro/mundo aparente a fim de situar o agir em outra dimensão, pois reconhece na instituição da idéia a desvalorização do mundo expressa filosoficamente em termos teórico e prático. Ainda assim, em nossa leitura, tal formulação não remeteria a uma lei para o agir, mas a um estado de assimilação do querer enquanto aceitação de tudo: do que se quis, do que se quererá, do que foi querido. Redimir o passado no homem não é faze-lo alterar o passado na escolha do presente que retornará, mas amá-lo como aquilo que foi. Se o homem é impotente para querer para trás, não é o lamento que conduzirá seu momento presente, mas sua potência maior manifesta-se justamente em afirmar o que foi. Essa é a redenção da vontade do lamento, do sofrimento e da dor. Uma tal afirmação, entretanto, não supõe, em nossa avaliação, nem uma regra prática nem um imperativo existencial, pois não há decididamente intervenção, deliberação, ou transformação do momento. Somente a travessia solitária de pôr-se a si mesmo a partir de uma nova perspectiva.
} 
sófico"4. Uma tal transposição tem implicações filosóficas profundas, já que se trata, por um lado, de extrair de uma total gratuidade conferida ao mundo e ao homem um redimensionamento de ambos e, por outro, de expressar, através de uma filosofia que diz não às interpretações precedentes, uma suprema afirmação.

Reconhecemos, no estabelecimento de uma complementaridade entre si e não e criar e destruir, o traço distintivo da transposição do dionisíaco em pathos filosófico em Nietzsche. Processa-se, de fato, uma transformação no conceito de negação anunciada através da predicação de complementaridade a pares disjuntivos. Em sua perspectiva, "o negar e o destruir são condição para o afirmar"s. A negação das perspectivas anteriores é condição para o advento de outras. Ao fazer do movimento traço distintivo dos existentes e ao conferir às suas produções, entendidas como interpretações, a mobilidade, ele a estende igualmente à negação e à destruição. E, nesse sentido, pode-se vincular a Nietzsche o desvinculamento da negação do princípio de contradição ${ }^{6}$, mediante a sua inserção no registro dos impulsos, forças e vontade de potência.

Quando afirmamos que Nietzsche retira a negação do princípio de contradição e a situa no registro dos impulsos, forças e vontade de potência, queremos resgatar a compreensão nietzschiana do vir-a-ser enquanto fluir constante que pode ser e não ser. Nietzsche segue Heráclito ao entender que o ser não deixa de ser o que é para se tornar outra coisa, mas é em fluxo. Na base do princípio de contradição, está a solução parmenídica ao problema metafísico segundo o qual o ser é e o não-ser não é. Efetivamente, Nietzsche busca dissolver, simultaneamente, os princípios de identidade e não-contradição por entender que eles sustentam a imutabilidade do ser que remonta a Parmênides ${ }^{7}$.

Antes de introduzir a vontade de potência como interpretação e entender toda proposição desde esse prisma, Nietzsche escreve em Humano, demasiado humano sobre a ausência de correspondência entre a lógica e o mundo real devido à pressuposição da identidade das coisas. Posterior-

${ }^{4} \mathrm{~F}$. NIETZSCHE, Ecce homo, O nascimento da tragédia, $\S 3$.

5 Idem, ibidem, Por que sou um destino, $\S 4$.

6 É importante mencionar que a primeira crítica e tentativa de dissolução dos princípios de não-contradição e identidade foi realizada por Hegel ao afirmar que tal princípio enuncia tão-somente a lei do entendimento abstrato e não uma lei universal do pensar (Cf. Hegel, Enciclopédia das ciências filosóficas. A ciência da lógica, Trad. Paulo Menezes, São Paulo, Loyola, 1995, § 115). Todavia essa autoria não é exposta e explorada por Nietzsche.

${ }^{7}$ Apesar de Nietzsche perceber em Aristóteles o reconhecimento de que a existência não faz parte da essência e, como não pertence à natureza das coisas, não é possível deduzir do conceito de ser a sua existência (Cf. FT § 10), recusa igualmente o princípio de contradição aristotélico tanto em sua formulação ontológica quanto lógica. 
mente, em 1888, vê o princípio de contradição como um esquema que sustenta o mundo verdadeiro, indicando, com isso, que os princípios da lógica são imposições perspectivas que permitem ao homem firmar o vir-a-ser a fim de domina-lo, não sendo determinações daquilo que existe. $\mathrm{Na}$ sua interpretação da efetividade como campo de batalha das forças, a afirmação e a negação são inseparáveis e podem ser colocadas ao mesmo tempo.

Sob um aspecto, entendemos que a negação na filosofia nietzschiana expressa a permanência da desagregação em determinada concreção orgânica e, sob outro, indica o necessário abandono dessa concreção para o aparecimento de uma outra. Afirmar a presença da negação e a sua necessidade enquanto suporte para a criação resulta numa visão de extrema complexidade da vida, pois se passa a assimilar as suas contradições como movimento necessário, embora não progressivo. Em Nietzsche, não há passagem de um estádio inferior para um superior mediante conciliações ou superações da negação. Diferenciamos a visão de Nietzsche, que entende a negação como movimento necessário no sentido da negação de uma perspectiva para a afirmação de outra, da negação na dialética hegeliana que supõe um movimento progressivo da tese à antítese.

Se em Hegel a tese contém a antítese, que é sua negação, e na síntese coexistem os dois opostos, em Nietzsche o alargamento de perspectivas requer a supressão de outras mais estreitas. Assim, a negação não se separa da afirmação embora rejeite a sua superação como na filosofia de Hegel. Em vista disso, Nietzsche contrapõe-se à afirmação hegeliana de que: "[c] constitui um dado capital da lógica a intelecção de que a natureza do pensar mesmo é dialética, de que o pensar enquanto entendimento deve necessariamente cair no negativo de si mesmo - na contradição"8. É em sentido diverso que o autor de Assim falava Zaratustra entende o pensar, não o separa do sentir e do querer, bem como a negação - não requer a sua superação como móvel do mundo ${ }^{4}$.

Reconhecemos como especificidade da abordagem nietzschiana acerca da negação a impossibilidade de negar a negação e de destruir a destruição. No limite, elas encerram uma positividade em um duplo sentido: condicionantes do par criação/afirmação e afirmação da negação. Transpor uma tal compreensão da vida e dos existentes, em discurso filosófico, significa compreender tragicamente o próprio fazer-se da filosofia enquanto fazer-se da vida que filosofia demandando, por isso, um outro tipo de discurso. O texto de Ecce homo, em que Nietzsche se considera o primeiro imoralista ${ }^{9}$, exprime, em certa medida, essa intenção ao relacio-

${ }^{8}$ HEGEL, Enciclopédia das ciências filosóficas. A ciência da lógica, Trad. Paulo Menezes, São Paulo, Loyola, 1995, § 11.

${ }^{9}$ A recusa de um tipo de moral e de homem está presente, via de regra, nos textos em 
nar a sua natureza dionisíaca à impossibilidade de separar: "o dizer Sim do fazer o Não"10. A própria alcunha de imoralista, enquanto destruidor par excellence encontra nessa medida de valor o seu sentido maior.

De fato, o imoralismo nietzschiano está ligado, indissoluvelmente, à destruição. Ainda assim consoante à sua natureza dionisíaca, não pode dissociar destruir e criar. Ao afirmar a relação presente entre o prazer de destruir e a força que lhe pertence para a destruição e, igualmente, ao reafirmar o elo existente entre Sim e Não, o filósofo assevera a correspondência entre força para destruir e destruir, recusando, conforme sua perspectiva filosófica, diferenciar força e produto da força e atribui ao Sim a medida do Não e ao Não a medida do Sim. Eis o ponto chave de nossa argumentação acerca do matiz principal de sua filosofia positiva estar em promover a destruição ao mesmo tempo em que procede à construção. Desse modo, é que o mais terrível poder ser, simultaneamente, o mais benéfico, mesmo sento "o destruidor par excellence".

Seguindo de perto suas declarações, são duas as negações que Nietzsche encerra enquanto imoralista" ${ }^{11}$. Em Ecce homo, diz negar "um tipo de homem que até agora foi tido como o mais elevado, os bons, os benévolos, os benéficos" 12 e acrescenta negar ainda "uma espécie de moral que alcançou vigência e domínio como moral em si - a moral da décadence, falando de modo mais tangível, a moral cristâa"13. É nelas que encontramos a contrapartida da construção. Tomando-se a proporção entre Sim e Não e Criar e Destruir como parâmetro, a negação de um tipo de homem requer um outro tipo, a negação de uma espécie de moral deman-

que Nietzsche intitula Imoralista. Veja-se o parágrafo 2 [185] do outono de 1885 /outono de 1886 e ainda 19 [9] do setembro de 1888,22 [25] do setembro de 1888.

10 F. NIETZSCHE, Ecce homo, Por que sou um destino, $\S 2$.

11 Há um terceiro sentido expresso na palavra imoralista que é caro a Nietzsche, qual seja, o de psicólogo. Ele se considera como sendo o primeiro psicólogo que houve, o primeiro a descobrir as tramas da moral judaico-cristã e a realizar a psicologia do sacerdote ascético. Em Ecce homo, Nietzsche afirma: “- Mas ainda em um outro sentido escolhi para mim a palavra imoralista como distintivo, distinção; orgulho-me de possuir essa palavra, que me distingue de toda humanidade. Ainda ninguém sentiu a moral cristã como abaixo de si: isso requeria uma altura, uma longevidade, uma até então inaudita profundidade ou 'abissalidade' psicológica. (...) Quem, entre os filósofos, foi antes de mim psicólogo, e não o seu oposto, 'superior embusteiro', 'idealista'? Antes de mim não havia absolutamente psicologia. ..." ( $E H$, Por que sou um destino, $\S 6$ ). Com relação à questão da psicologia em Nietzsche, vale citar o estudo de P. Wotling: "Der Weg zu den Grundproblemen. Statut et structure de la psychologie dans la pensée de Nietzsche". In: Nietzsche-Studien, 26, Berlin, Walter de Gruyter \& Co, (1997), 1-33.

12 Idem, ibidem, Ecce homo, Por que sou um destino, § 4.

13 Idem, ibidem. 
da uma outra espécie, ainda que a sua construção exija a completa dissolução das interpretações anteriores e o assentamento de uma moral e de um sujeito em outras bases. Nesse caso, compreendemos a inserção do trágico no âmbito filosófico enquanto suporte de um redimensionamento do sujeito em termos éticos. Há, na filosofia de Nietzsche, uma relação entre o trágico e ético, cuja elucidação tem no elemento dionisíaco presente nesta filosofia à chave de interpretação.

Ainda que a primeira ocorrência do dionisíaco esteja ligada à elaboração de uma metafísica de artista, situando-se, assim, na exposição referente ao nascimento da tragédia Ática, passa por revisões que resultam em uma ampliação do seu uso e sentido nos textos subseqüentes. No ensaio Tentativa de autocrítica, cujo objetivo principal está na retomada de algumas questões postas em $O$ nascimento da tragédia, Nietzsche admite haver sido pouco cauteloso ao elaborar uma resposta sobre o sentido do dionisíaco, considerando que talvez devesse ser mais prudente com referência a essa questão: "Talvez eu falasse agora com mais precaução e com menos eloqüência acerca de uma questão psicológica tão difícil como é a origem da tragédia entre os gregos" 14 . Poderíamos perguntar por que o filósofo predica, ao mesmo tempo, "sabedor" e "precaução" ao seu discurso. As aspas em "sabedor" indicam que um sentido oposto pode ser conferido ao termo ${ }^{15}$. Precaução, por seu turno, não é uma característica que se possa atribuir a Nietzsche, apesar de o autor requerer a companhia da prudência na figura da serpente, "o animal mais prudente debaixo do sol"16. Que questões perpassam a ausência de sabedoria e de precaução permitindo que se apreenda o dionisíaco ${ }^{17} \mathrm{e}$, ademais, sua relação com o ético em Nietzsche? Ora, talvez o filósofo responda à pergunta ao anunciar uma questão de fundo presente em $O$ nascimento da tragédia:

14 Idem, Tentativa de autocrítica, $\S 4$

15 Compartimos com Eric Blondel a compreensão acerca do uso das aspas nos textos de Nietzsche. Realmente, não se trata de um uso parcimonioso, já que encontramos esse sinal gráfico em praticamente todos os textos de Nietzsche e, via de regra, como assinala Blondel, eles recortam campos de significação, querendo separar do discurso nietzschiano algo que a ele não pertence. Em vista disso, observamos aqueles termos que remetem à fixidez, à moral e à causalidade aparecerem, geralmente, entre aspas. (Eric Blondel, "As aspas de Nietzsche: filologia e genealogia" in: Nietzsche hoje?, seleção e apresentação de Scarlett Marton, Brasiliense, 1985).

16 F. Nietzsche, Assim falava Zaratustra "Prefácio" $§ 10$.

17 Em sua revisão de $O$ nascimento da tragédia, Nietzsche tenciona desvincular suas perspectivas, por um lado, da filosofia de Schopenhauer e, por outro, da música wagneriana, isto é, das expectativas que depositara no compositor alemão. Conforme, principalmente, o parágrafo quinto do ensaio Tentativa de autocrítica e o texto de Ecce homo referente ao Nascimento da Tragédia. 
"[o] que significa, vista sob a óptica da vida - a moral?"18.

Não se pode ser por acaso que o parágrafo quarto inicie perguntando pelo sentido do dionisíaco e termine justamente com a questão acerca do significado da moral em sua relação com a vida. Em que pese a proliferação de interrogações acerca dos gregos, da tragédia, da dor, do pessimismo, etc. que o parágrafo concentra, há um elo entre compreensão do trágico, através de Dioniso, que permite suplantar a moral. Na própria avaliação de Nietzsche, ao propor uma metafísica de artista em $O$ nascimento da tragédia, ele termina por elaborar uma contravaloração, que afirma a vida e nega a vigência da moral: "Contra a moral, portanto, voltou-se então, com este livro problemático, o meu instinto, como um instinto em prol da vida, e inventou para si, fundamentalmente, uma contradoutrina e uma contravaloração da vida, puramente artística, anticristâ" 19 . $\mathrm{Na}$ seqüência do texto, Nietzsche denominará de dionisíaca esta primeira contraposição entre a interpretação moral da existência, que consiste na negação da vida e, de outro, a sua afirmação, que enquanto visão artística denominada por Nietzsche de dionisíaca, ultrapassa a moral.

Como nesse momento a arte figura como atividade propriamente metafísica do homem, o deu, na visão do filósofo, é um "deus-artista inconsiderado e amoral". Criando e destruindo sem responsabilidade pessoal, pois é inconsiderado e amoral, atinge simultaneamente autocracia e distância dos sofrimentos. Ora, enquanto em $O$ nascimento da tragédia é a via da arte que se põe contra a significação moral conferida à existência, será o redimensionamento do trágico que remeterá a uma compreensão ética possibilitadora, então, da dissolução da moral da responsabilidade, da auto-renúncia e do sacrifício de si em favor de uma aceitação incondicional da vida enquanto atitude ética.

Nesse sentido, é interessante analisar o texto de 1885 em que Nietzsche afirma querer resgatar a inocência do vir-a-ser desde há muito tempo, retomando as construções por ele elaboradas com tal intuito: "Há quanto tempo já venho tentando demonstrar a inocência do vir-a-ser! E que caminhos estranhos tive de passar para faze-lo!"20. Inicialmente, compreender a arte como via possível; na seqüência, concilia a desvalorização objetiva da culpa e a imputação subjetiva do injusto e alógico à existência e, por fim, afirma a ausência absoluta de objetivos ligados a conexões causais como via de acesso ao seu próprio objetivo. O filósofo desvincula a existência da jurisdição da moral e afirma ser a vida injusta e alógica. Mas qual o sentido de uma tal afirmação senão proceder à superação das

\footnotetext{
18 F. Nietzsche, Tentativa de autocritica, $\S 4$.

19 Idem, ibidem.

20 Idem, Fragmentos Póstumos de 1885, 36 [10].
} 
interpretações que antecedem a sua, ao mostrar que, atrelada ao vir-a-ser, a jurisdição da moral termina por retirar-lhe a inocência? Seu itinerário reflexivo busca ultrapassar essas prerrogativas e devolver a inocência, cara ao vir-a-ser, por ser entendida como sua condição. Assim, por exemplo, a arte aparece como contra-ponto inicial. Todavia, não é o termo da exposição, mas a primeira via de acesso ao problema. Em nossa ótica, as formulações que o filósofo retoma permitem, simultaneamente, identificar o eixo temático de suas inquietações, qual seja, a inocência do vir-a-ser e a interpretação moral da existência e a necessidade de formular uma interpretação que dê conta, ao mesmo tempo, da inserção atuante do homem no mundo e do mundo enquanto inocência intrínseca.

Apresentamos o redimensionamento do sujeito em termos éticos, como uma resposta que permite desvincular a avaliação da culpa, já que tem, na tragicidade do vir-a-ser, a emergência do acontecer. Nesse caso, à margem de qualquer elogio e de qualquer acusação. Por isso, lemos a irresponsabilidade que o filósofo se atribui enquanto ponte para seu objetivo como uma rejeição mais ampla, por concentrar a recusa das interpretações que derivam o dever do ser. Afinal, na base de sua interpretação está o vir-a-ser, por si mesmo, inocente, e é no âmbito desta inocência que se pode imputar irresponsabilidade mora. Resta, porém, uma questão: como é possível pensar em um sujeito ético sem a imputação da responsabilidade moral? Eis uma questão de difícil solução caso se torne a ação na perspectiva da decisão pessoal, pois, nesse caso, o corolário é a responsabilidade do agente. A construção de Nietzsche, entretanto, prescinde dessa condição ao pensar o sujeito em uma dimensão de fatalidade trágica que tem, nos sentidos do dionisíaco, sua via de acesso.

A partir da elaboração de Assim falava Zaratustra, Nietzsche passa a conferir ao deus grego outro destaque, ao incorporar a vertente eminentemente positiva da sua filosofia, no sentido de uma ruptura com a tradição, ao pathos dionisíaco. Desde então, em maior ou menor intensidade e ocorrência, esse pathos dominará a sua cena filosófica ${ }^{21}$. É recorrendo a Dioniso que o filósofo de Sils Maria propõe a afirmação da vida como medida de sua aceitação e expressão ascendente. Ao comentar esta obra, Nietzsche afirma: "Meu conceito de 'dionisíaco' tornou-se ali ato supremo"22. Ora, Zaratustra, enquanto porta-voz do discurso nietzschiano, recebe a incumbência de incorporar, ao mesmo tempo, a destruição e a criação supremas.

21 Nossa referência endereça-se, especialmente, aos textos escritos a partir de Assim falava Zaratustra, já que, nesses textos, Nietzsche elabora sua filosofia positiva. Ainda assim, o filósofo atribui ao período que o antecede, particularmente à elaboração de $A$ Gaia ciência, por introduzir, no quarto livre, "o pensamento básico de Zaratustra" a manifestação em si de uma vertente excessivamente afirmativa.

22 F. Nietzsche, Ecce homo, “Assim falava Zaratustra”, § 6. 
A ele coube, por um lado, dissipar a moral, o ideal de um homem moderno, a teleologia no mundo, mas, por outro lado, foi aquele que anunciou o advento do além-do-homem, a vida enquanto vontade de potência, a doutrina do eterno retorno e, em nossa ótica, a ética do amor fati. Considerando Zaratustra o afirmador par excellence, Nietzsche o vê como aquele que constrói sobre escombros, extrai do mais pesado dos pesos à leveza. Em suas palavras, "[e]le contradiz com cada palavra, esse mais afirmativo dos espíritos; nele todos os opostos se fundem numa nova unidade"23. Mais importante fusão que se possa imaginar é, segundo Nietzsche, a promovida por Zaratustra, qual seja, a da temporalidade. É a doutrina do eterno retorno, que condiz com sua aspiração mais profunda. Todavia, até o seu anúncio outras fusões se processam, novas perspectivas aparecem, entre elas, a do além-do-homem como sujeito ético. Dioniso, deus grego da metamósphosis, é mais do que uma inspiração é uma espécie de fonte para a geração do novo. Por isso, Nietzsche chega a considerar-se seu discípulo.

Dioniso aparece, nos textos de Nietzsche, ora como um deus, ora como um filósofo; por vezes, ainda, como seu alter ego ${ }^{24}$. Essas formas de exprimir Dioniso estão condensadas na leitura mitológica que o pensador alemão faz do deus grego e são expressas nas personagens do seu discurso filosófico, especialmente em Zaratustra. Mas há uma rejeição para si e para Zaratustra da alcunha de profeta, entendido enquanto construtor de um novo ídolo ou melhorador da humanidade, pois não é nesse viés que se pode aproximar Nietzsche, Zaratustra e Dioniso. Em várias ocorrências, o filósofo rejeita essas intenções. Com relação à humanidade, afirma jamais desejar melhorá-la. Em termos de edificação de ideais, remete sempre ao seu ofício de destruidor de ídolos. Assim identificamos na ordem de uma aquiescência profunda a ligação entre Nietzsche, Zaratustra e Dioniso. O filósofo alemão apresenta-se como o espírito afirmador por excelência, a personagem Zaratustra rejeita todo tipo de objeção à vida e Dioniso encarna ambas as atitudes no prazer irrestrito de criar e destruir que, em Nietzsche, o caracteriza. Daí o filósofo, ao se referir a Zaratustra em Ecce homo, identificar na personagem, aparentemente em duas dimensões, a "idéia do Dioniso".

Primeiramente, enquanto singularidade do tipo, como uma espécie de traços de caráter que tem no acesso aos extremos a sua característica básica; na necessidade do acaso a singularidade definidora, assim como

23 Idem, ibidem.

24 Dioniso aparece, em diversos textos, ligado ao grande meio-dia e à filosofia do eterno retorno. Observem-se, por exemplo, os seguintes fragmentos: 34 [191], [192], [201] do abril/junho de 1885. Meio-dia, eterno retorno e aquiescência profunda estão interligados na filosofia de Nietzsche e têm, em nossa visão, relação direta com a ética do amor fati. 
na confusão com o vir-a-ser e na perda de si para seu encontro no múltiplo à expressão de Dioniso ${ }^{25}$. Em um segundo momento é em termos de atitude que a parecença tem relevo, pois é o caráter ilimitado da afirmação daquele que tem em seu dizer um supremo não que remete agora a Dioniso. Zaratustra diz não sem ser, no entanto, um negador: “'A todos os abismos levo a benção do meu Sim'... Mas esta é a idéia do Dioniso mais uma vez"26. Outra vez a idéia do deus é parâmetro para o esclarecimento de Zaratustra. Todavia, não se trata de questões passíveis de distinção, pois as duas ordens assemelham-se no vir-a-ser. Produto/processo, agir/agente, ser/vir-a-ser são como as duas faces de uma moeda, cuja separação acarretaria a sua perda. Logo, a condição do tipo é condição da ação desse tipo, já que não é possível antepor o ser ao agir, o ser ao dizer, o ser ao vir-a-ser. Em ambos está o movimento, o fluxo e o refluxo; enfim, a determinação do vir-a-ser.

Dessa compreensão advém uma potência sem medida para a mudança, a metamorfose; em suma, a transformação completa que interliga agir e agente, processo e produto. No limite, Dioniso expressa, no plano filosófico nietzschiano, o exercer-se da força, o efetivar-se. Recorrendo à figura do deus grego, o pensador alemão apresenta as condições necessárias para uma assimilação da vida sem subterfúgios, isto é, sem a construção de ídolos ou ideais. Por conseguinte, a dureza do tipo ser pré-condição para seu papel de aniquilador e construtor ${ }^{27}$. Dioniso é um

25 Nesse parágrafo, Nietzsche cita, em seu comentário em Ecce homo acerca do livro Assim falava Zaratustra, um texto constante na terceira parte do referido livro. 'De velhas e novas tábuas', para elucidar o sentido do Dioniso e sua possível identificação com o sentido da personagem Zaratustra. Um tal recurso, longe de ser fortuito, visa a apresentar, ao mesmo tempo, sua visão do deus grego, a partir da caracterização de Zaratustra, e deste enquanto manifestante do fluxo e refluxo característicos do deus. Em 'De velhas e novas tábuas' estão presentes o sim e o não, o criar e o destruir que, enquanto pares complementar, fazem brotar do extremo não de Zaratustra o ilimitado sim e amém.

26 F. Nietzsche, Ecce homo, Assim falava Zaratustra, § 6.

27 Em Nietzsche, a "natureza dionisíaca" manifesta-se também através da condição de força existente para o destruir. Ser duro, nesse sentido, equivale a não fazer concessões ao estabelecido, aos ídolos e ideais existentes, mas, ao contrário, fazer-se martelo diante dos valores que desvalorizam a vida. A metáfora do martelo exprime justamente o prazer no destruir, condição básica de todo aquele que poderá criar. Em Ecce homo, assim a descreve: "Entre as precondições para uma tarefa dionisíaca, é decisiva a dureza do martelo, o prazer mesmo no destruir. O imperativo: 'tornai-vos duros!', a mais básica certeza de que todos os criadores são du$r o s$, é a verdadeira marca de uma natureza dionisíaca" ( $E H$, Assim falava Zaratustra, § 8). Em Crepúsculo dos ídolos, manifesta-se essa prerrogativa dos criadores desde o título e, principalmente, no subtítulo do livro: "como filosofar com o martelo". Quanto ao sentido de um tal filosofar, o autor o esclarece ainda no prólogo: "Este pequeno escrito é uma grande declaração de guerra; e no que concerne à ausculta dos ídolos, é importante ressaltar que os que estão em jogo, os que aqui 
dançarino e um destruidor; Zaratustra também é um dançarino e um destruidor. Em ambos os casos, manifesta-se a vida enquanto vontade de potência que institui e destitui interpretações. É a transposição do dionisíaco em pathos filosófico que, enquanto pano de fundo do discurso nietzschiano, remete sua filosofia positiva para a expressão do trágico e viabiliza apreender, nessa dimensão, a construção do ético.

Em suas considerações acerca de $O$ nascimento da tragédia, afirma: "Eu prometo uma era trágica: a arte suprema do dizer Sim à vida, a tragédia, renascerá quando a humanidade tiver atrás de si a consciência das mais duras, porém necessárias guerras, sem sofrer com isso..."28. O sentido dessa afirmação é claro: há uma ligação indissolúvel entre trágico e afirmativo, entre trágico e dizer Sim; em suma, entre a suprema afirmação e a situação trágica da vida. Por conseguinte, a proposição de uma outra atitude diante da vida, de uma outra forma de expressar-se da vida mesma que dê vazão ao seu criar irrestrito enquanto vontade de potência. Condições manifestas pela vida e expressas em uma filosofia afirmativa por excelência, em uma filosofia, nesse sentido, eminentemente trágica e, desde esse horizonte, ética ${ }^{29}$.

Ora, para que a tragédia, entendida enquanto Sim irrestrito, renasça, há de se processar no homem uma alteração em termos de compreensão e ação. Efetivamente, o sofrimento diante do imponderável deve ser substituído pela sua aceitação; à recusa dos desígnios de ascensão e declínio próprio do vir-a-ser deve seguir-se o seu testemunho. Dessa condição, emerge o ético enquanto incorporação e expressão do trágico. Ao conferir gratuidade também ao agir, o filósofo transformaria a intenção em condição, o dever em imposição de perspectiva e o ser em vir-a-ser, dimensionando o ético pela experiência, no sentido de vivência, do trágico. Os

são tocados com o martelo como um diapasão, não são os ídolos em voga, mas os eternos" (CI, Prefácio).

28 F. Nietzsche, Ecce homo, O nascimento da tragédia, § 4.

29 Em um fragmento póstumo de 1888, denominado 'Novo caminho para o 'sim', encontra-se novamente a ligação existente entre o dionisíaco dizer sim, manifesto em sua expressão de tragicidade, e a compreensão que Nietzsche tem da filosofia: "A filosofia, tal como a tenho compreendido e vivido até este momento, é uma investigação voluntária dos aspectos mais detestados e infames da existência" e, na seqüência, acrescenta: "Uma filosofia experimental, tal como eu a vivo, antecipa experimentalmente até mesmo as possibilidades do niilismo radical; sem querer dizer com isso que ela se detenha em uma negação, no não, em uma vontade de não. Ela quer, em vez disso, atravessar até o inverso - até a um dionisíaco dizer-sim ao mundo, tal como é, sem desconto, exceção e seleção" (16[32] da primavera/verão de 1888). Nessa passagem, Nietzsche retoma a dimensão por ele conferida ao não, já que não se trata de ficar preso à negação, mas de afirma-la como passagem para o sim. Por outro lado, o sim condensa todos os aspectos da existência, afirmando o seu caráter trágico que condiz com sua visão de filosofia. 
determinantes do querer e do agir estão ligados no efetivar-se enquanto ser mais. Manifestam-se, indistintamente, como pensar, querer e sentir, expressos na perspectiva imposta tanto em termos de regra de vida quanto na forma de acesso ao conhecimento. Em vista disso, a emergência, característica na filosofia de Nietzsche, de uma vinculação entre ação e representação, pensamento e vida, teoria e prática que nos permite à unidade do sujeito ocidental, cognoscente e moral, o sujeito além de bem e mal.

Dioniso, ao ser apresentado como tipo do legislador ("IV. Dioniso, Tipo do legislador"30, e ao ser contraposto ao Crucificado, “- Fui compreendido? - Dioniso contra o Crucificado..."31, vem, justamente, corroborar a hipótese da construção de uma outra perspectiva ética em Nietzsche e do além-do-homem enquanto seu sujeito ${ }^{32}$. Num primeiro momento, Nietzsche recorreu à arte para dissipar a moral e devolver a inocência ao vir-a-ser. Todavia, a partir de Assim falava Zaratustra, é à vontade de potência, o além-do-homem e o eterno retorno que aparecem como perspectiva que, ultrapassando os velhos ídolos e ideais, redefinem sujeito e mundo, assim como sua ação e compreensão. Ora, Dioniso como deus da metamorfose, é portador de uma nova legislação, qual seja, a do vir-a-ser ${ }^{33}$. Portanto a fluidez em detrimento da fixação contrapõe-se ao Crucificado por ele condensar uma legislação que condena o homem ou ao sentido imaginário, crença nos valores transcendentes enquanto absolutos, ou à perda total de sentido, crença no Deus cristão e a conseqüente precipitação no niilismo. Em vista disso, Nietzsche refere-se a Dioniso e ao Crucificado como dois tipos que manifestam, respectivamente, a ascensão e o declínio. De fato, a oposição existente é entre Dioniso e o Crucificado por introduzirem significados diversos ao martírio, pois enquanto a crucificação traz em seu bojo a negação da vida, o Dioniso cortado em pedaços remete à promessa de vida. Eis o sentido de eternamente renascer e voltar da destruição. Mas como o criar caracteriza Nietzsche e suas personagens tanto ou mais do que o confrontar, pois lhe coube redi-

30 F. Nietzsche, Fragmentos Póstumos de 1888, 23 [8].

31 Idem, Ecce homo, Por que sou um destino, § 9.

32 Em um fragmento póstumo de 1888, Nietzsche, fazendo alusão ao que seria ser superior, no caso ser imoralista, coloca-se para além de bem e mal, e afirma a crença no Olimpo em detrimento de uma fé no Crucificado (Cf. 16 [16] da primavera/verão de 1888).

33 Dioniso aparece como portador de uma transformação, de uma nova legislação, enfim, de um grande meio dia em muitos parágrafos constantes nos Fragmentos póstumos de 1885 . Veja-se, por exemplo, § 34 ([182], § 34 [91], § 34 [201] do abril/junho de 1885. Especialmente no $\S 34$ [248] do abril/junho de 1885, resgatando a dupla face do deus, Nietzsche o denomina "educador, enganador, destruidor, criador" expressando, de forma sucinta, as perspectivas desenvolvidas em $\mathrm{Pa}$ ra além de bem e mal, § 295. 
mensionar o não ao dar-lhe a contrapartida imediata do sim, à contraposição de Dioniso ao Crucificado deve seguir-se uma afirmação. Compreendendo-se o Crucificado como tipo da moral judaico-cristã, a proposição de uma nova legislação demanda um outro tipo que possa vive-la. Se a aquiescência profunda requer uma transformação em termos de conduta humana, esta transformação manifesta-se em termos éticos e o homem; nesses sentido, aparece como sujeito ético. Ao compreender o martírio como promessa de vida, o homem transforma-se, transmuta-se, vem a ser outro. Passa a incorporar o trágico como medida da vida; logo, a inocência torna-se inalienável, extirpando a perspectiva de culpe e, conseqüentemente, de condenação. Não se trata mais do ideal de homem cristão, mas de um para além da visão cristã; logo, uma ultrapassagem da compreensão de homem vigente até essa transformação.

Compreendemos em Nietzsche a introdução do conceito de Übermensch enquanto horizonte da eticidade no sujeito desde a incorporação do trágico. A contraposição do além-do-homem aos homens supremos, ao fornecer a chave para a compreensão do querer zaratustriano, remete às perspectivas por ele introduzidas que remontam ao próprio sentido do além-do-homem na filosofia de Nietzsche. Ora, os homens supremos, aos quais o filósofo se refere, não possuem grandeza no sentido de ousar e criar; ao contrário, são animais de rebanho que ascenderam à posição de supremos dentro de uma determinada perspectiva. Ultrapassá-la é dirigir-se ao além-do-homem, é abandonar os homens excelsos em prol de um redimensionamento da valoração.

A personagem Zaratustra exprime o reconhecimento, na verdade, de uma pseudograndeza ao manifestar o cansaço que ela lhe inspira. Contrapondo ao supremo, ao bom, ao saudável de uma perspectiva decadente, um outro tipo, Nietzsche, através de Zaratustra, faz da aproximação com os maus o estabelecimento necessário de uma proximidade com o oposto dos tipos supremos de uma perspectiva por ele sumariamente rejeitada: "Zaratustra, o primeiro psicólogo dos bons, é - em conseqüência - um amigo dos maus" 34 . É ao compreender a bondade dos homens supremos no domínio de uma decadência fisiológica, que o psicólogo dos bons deve se aproximar dos maus. Eis o sentido das inversões em termos de nomenclatura: o supremo de um tipo é o oposto para o outro. Isso se manifesta, também, na percepção, por parte dos supremos, do além-do-homem zaratustriano como demônio. Nesse caso, é o revolver das crenças desses homens, sintetizadas na capacidade de ousar e criar pertencentes por condição e expressas na proposição de uma nova ação por parte do além-do-homem, que os leva a considera-lo como terrível.

34 F. Nietzsche, Ecce homo, Por que sou um destino, $\S 5$. 
Com efeito, é a mudança de compreensão e ação que determina o além-do-homem nietzschiano, pois, nas afirmações do filósofo, "esse gênero de homem que ele [Zaratustra] concebe, concebe a realidade como ela é: ele é forte o bastante para isso" 35 . De uma parte, o filósofo ressalta a relação existente entre percepção da realidade e força para uma tal percepção, equiparando ser e conceber em um tipo de sujeito para além dos bons e justos. De outra, é a utilização do verbo 'conceber' colocado, ao mesmo tempo, em Zaratustra e no seu tipo de homem que remete à introdução de uma perspectiva e permite entender por efetividade o conjunto de perspectivas, pois Zaratustra concebe um tipo que concebe a realidade como ela é. Consoante Nietzsche, ser é vir-a-ser e vir-a-ser é ser, pois ele confere efetividade ao mundo somente enquanto jogo de forças de combinações alteradas. Assim, realidade é transitoriedade, no sentido de conjunto de perspectivas que se alargam constantemente. Sentir e exprimir, dessa forma, ser e valor é sentir e exprimir a própria efetividade sem distanciamentos ou distorções e, em vista disso, ter em si a problematicidade da existência, encarnar a tragicidade da vida, único requisito que, em Nietzsche, confere grandeza ao homem.

Nenhum dos homens, entretanto, manifestou, para Nietzsche, tais prerrogativas. Ao contrário, em suas afirmações ele expressa que foi o conhecimento dos bons e dos melhores que lhe remeteu à busca de um para-além deles. Em Ecce homo, comenta: "Zaratustra não deixa nisso dúvidas: diz haver sido precisamente o conhecimento dos bons, dos 'melhores', que lhe inspirou o horror ao homem" ${ }^{36}$. Novamente o filósofo indica que o além-do-homem está para além do entendimento de bondade e melhoria com que se definia o homem em um tipo de compreensão. Daí ele determinar a grandeza desse homem, circunscrita na esfera do absoluto, em uma palavra: transição. Efetivamente, é enquanto ancestral do além-do-homem que ele, na visão nietzschiana, se faz maior, já que, no prólogo do livro, faz um elogio ao amor da personagem ao homem, mas afirma que este deve ser superado e anuncia o além-do-homem nos discursos de número três e quatro. No quarto, especialmente, utiliza dezenove vezes o verbo amar. Em sua primeira ocorrência (§ 4), diz: "O que há de grande no homem, é que ele é uma ponte e não um fim: o que pode ser amado no homem, é que ele é um passar e um sucumbir"37. Explicita-se, especialmente nessa passagem, o significado do amor aos homens segundo Zaratustra, entendido como transição para o além-do-homem. Ora, é a ponte, a outra margem, o sacrifício, o perecer, em suma, o declínio, en-

35 Idem, ibidem.

36 Idem, ibidem.

37 Idem, Assim falava Zaratustra, "Prólogo" § 4. 
quanto complemento do verbo 'amar', que é amado no homem, visto ser condição para o além-do-homem. Contudo, o homem foi definido pelo filósofo, em outra seção, como estimador. Esse é o sentido de "Mensch", resgatado por Nietzsche em 'Dos mil e um alvos', mas também é apresentado como ponte, assim aparecendo na maior parte dos trechos de Assim falava Zaratustra. Nesse caso, ou o além-do-homem (Übermensch) está para o homem (Mensch), no sentido de para além do estimador, ou para além de um tipo de estimação. Como, na ótica de Nietzsche, "sem o estimar a noz da existência seria oca"38, e ele não vê outro modo de estar no mundo salvo o interpretante, tem-se de concluir que o além-do-homem nietzschiano está além de um determinado tipo de estimação, o que, por outro lado, requer estar para além de uma determinada condição fisiológica.

Houve muitas tábuas de valores, mas nenhuma delas expressando o vir-a-ser. Se uma inscrição dessa ordem propõe um redimensionamento em termos de compreensão do agir e do próprio agir, é nessa dimensão que julgamos estar o sentido do Übermensch nietzschiano. Por isso, diz Zaratustra, "[m]il alvos houve até aqui, já que houve mil povos. Falta inda apenas o grilhão para as mil nucas, falta o alvo único"39. Unicidade, no entanto, não é predicativo do vir-a-ser e, tampouco, das formulações de Nietzsche. Ainda assim, a personagem afirma faltar esse alvo único. Retomando-se a formulação referente a Zaratustra, no sentido de promover novas unidades, a mesma pode ser entendida enquanto recusa da unidade do ser e, com isso, da distinção entre ser e vir-a-ser. Ora, enquanto porta-voz do discurso nietzschiano, a personagem manifesta justamente a aspiração do filósofo, qual seja, a de "[i]mprimir ao vir-a-ser o caráter de ser - isto é a suprema vontade de potência" (7 [57] do final de 1886/primavera de 1887). Numa inovação que remonta, em alguns aspectos, a Heráclito, Nietzsche introduz a mobilidade no ser e, com isso, o entende como vir-a-ser.

Inicialmente, o filósofo alemão recusa a presença, seja, de um ser perfeito, imutável, pleno, seja de uma privação absoluta de perfeição, imutabilidade, de plenitude, em suma, de ser. Se o vir-a-ser não tem um estado final, então não se converte em ser. Se sua determinação fosse deixar de ser, converte-se em não ser, já teria deixado. Logo, caso se queira falar em ser, só se pode faze-lo com referência ao que devém, ao vir-a-ser que, efetivamente, se manifesta. Imprimir ao vir-a-ser o caráter de ser é, por um lado, retira-lo da posição intermediária, conferida a ele por Platão, entre o ser e o não-ser e, por outro, recusar a hipótese de que haja algo de incondicionado. Se não há ser, enquanto unidade estável,

38 Idem, ibidem, Dos mil e um alvos.

39 Idem, ibidem. 
nem não-ser, entendido desde a ausência de ser, e tampouco um domínio incondicionado que oculte o ser, a oposição ser/vir-a-ser perde o referencial de sua proveniência, perde a eficácia em termos de construção do conhecimento e do mundo, em suma, perde o sentido e o valor. Imprimir ao vir-a-ser o caráter de ser é, em Nietzsche, destituir, ao mesmo tempo, o valor do ser e do não-ser conforme a história da filosofia. Como a existência, nessa visão, não é uma categoria da unidade do ser mas manifestar-se do vir-a-ser enquanto ser, há uma impossibilidade de encontrar a permanência, a ordem, o fim e o absoluto em quaisquer domínios existentes, possibilitando introduzir o ético em novo domínio.

Consoante as palavras de Zaratustra, à humanidade falta um alvo, cuja privação determina a sua ausência: "Mas dizei-me, meus irmãos: se à humanidade ainda falta um alvo, não será porque falta, ainda, a própria humanidade?"40. Recorrendo à dotação de um duplo sentido à palavra humanidade, Nietzsche distingue duas perspectivas acerca das tábuas valorativas, pois, embora tenha havido muitos alvos, falta o alvo único. De um lado, concentra, na primeira ocorrência do termo humanidade, os diversos cultos havidos no decurso da história em torno dos valores bem e mal: "Muitas terras viu Zaratustra, e muitos povos; nenhum poder maior encontrou Zaratustra, na Terra, do que as obras dos homens amantes: 'bem' e 'mal' é o seu nome" 41 . De outro, o alvo faltante, cuja presença viabilizaria ao termo humanidade uma dimensão positiva.

Vale acrescentar que o conceito de humanidade, citado por Nietzsche em Assim falava Zaratustra, que designar mais o reconhecimento de uma condição do que de uma igualdade constitutiva dos homens expressa na reunião de todos eles. A falta de uma humanidade deve, por conseguinte, indicar a inexistência de um tipo de procedimento. Se os povos se deram, até então, seu bem e seu mal e, ainda assim, não encetaram o alvo único, determinando uma ausência da humanidade, então a sua possibilidade está no encontro desse alvo. O que está em questão é a percepção de si enquanto ser mais, enquanto ser avaliador, destruidor, em suma, criador. O que falta é um redimensionamento de compreensão e ação e, por conseguinte, o entendimento do sujeito em uma outra dimensão. Um tal alvo, ao ser encetado, aponta para o começo da humanidade por marcar uma ruptura com os cultos anteriores que se processará a partir do além-do-homem, isto é, ele poderá e deverá vivê-lo, resgatando, por um lado, o sentido de estimador pertencente ao Mensch, mas, por outro, ultrapassando o modo de avaliar realizado até o seu próprio advento, por conseguintes, o Übermensch. No conceito de além-do-homem, Nietzsche exprime a condição humana de incorporação do pathos afirmativo por

40 Idem, Assim falava Zaratustra, I, Dos mil e um alvos.

41 Idem, ibidem. 
excelência. É ele que realiza a travessia que conduz do trágico ao ético, definido-se pela superação concomitante do pessimismo e do niilismo. No limite, ao dizer sim à vida, ele exprime a abertura ao vir-a-ser reconhecendo a tragicidade do acontecer: "ser em si mesmo o eterno prazer do vir-a-ser - esse prazer que traz em si também o prazer no destruir..."42.

\section{Bibliografia}

BLONDEL, Eric, Nietzsche le corps e la culture, Paris: PUF, 1986.

"Critique et généalogie chez Nietzsche, ou Grund, Untergrund, Abgrund". Revue philosophique de la France et de l'étranger. Paris, PUF (1999). T. CLXXXIX. pp. 199-210.

DELEUZE, Gilles, Nietzsche et la Philosophie, Paris, PUF, 1962.

HAAR, Michel, Nietzsche et la métaphysique, Paris, Gallimard, 1993. - Par-delà le nihilisme, Paris, PUF, 1998.

MAGNUS, Bernard, "Eternal recurrence", Nietzsche Studien, 8 (1979), 362-77. "Nietzsche's eternalistic counter-mith", Review of Metaphysics, 26 (junho de 1973).

Nietzsche's Existencial Imperative. Bloomington, Indiana University Press, 1978.

NIETZSCHE, Fr. Sämtliche Werke - Kritische Studienausgabe, edição organizada por Giorgio Colli e Mazzino Montinari, Berlim, Walter de Gruyter \& Co., 1967/1978. 15 vols.

NIETZSCHE - Obras Incompletas, coleção "Os Pensadores", tradução de Rubens Rodrigues Torres Filho, São Paulo, Abril Cultural, 1978. Nos trechos em que possível, reportamo-nos a esta fonte.

\section{RESUMO}

Este artigo procura mostrar que a transposição do dionisíaco em pathos filosófico remete a filosofia positiva de Nietzsche para a expressão do trágico e viabiliza apreender, nessa dimensão, a construção do ético. Introduz o conceito de Übermensch enquanto horizonte da eticidade no sujeito desde a incorporação do trágico enquanto expõe um redimensionamento em termos de compreensão do agir e do próprio agir.

Palavras-chave: trágico, ético, dionisíaco, além-do-homem

42 Idem, Ecce homo, O nascimento da tragédia, § 3. 


\begin{abstract}
This paper aims at showing that the transposition of the Dionysian into philosophical pathos leads Nietzsche's positive philosophy to the expression of the tragic and gives way to the apprehension of the construction of the ethic. It posits the concept of Übermensch as the horizon of the ethicity of the subject by the embodiment of the tragic. At the same time, this paper advances a shift in terms of understanding the acting and the acting itself.

Key words: the tragic, the ethic, Dionysian, overman.
\end{abstract}

